\title{
Paradoxical tensions and corporate sustainability: A focus on circular economy business cases
}

\author{
Tiberio Daddi ${ }^{1}$ (D) | Domenico Ceglia ${ }^{2}$ | Guia Bianchi ${ }^{1}$ | Marcia Dutra de Barcellos ${ }^{2}$
}

${ }^{1}$ Institute of Management, Sant'Anna School of Advanced Studies, Pisa, Italy

${ }^{2}$ Postgraduate Programme in Management (PPGA/UFRGS), Federal University of Rio Grande do Sul, Porto Alegre, Brazil

Correspondence

Tiberio Daddi, Institute of Management, Sant'Anna School of Advanced Studies, Piazza Martiri della Libertà 33, Pisa 56127, Italy.

Email: tiberio.daddi@sssup.it

\begin{abstract}
The paradoxical tensions in corporate sustainability is hotly debated in the literature. Some authors have underlined the need for empirical works in this field, and the circular economy could help to bridge this gap. The circular economy creates contrasting challenges for companies, which lead to paradoxical tensions. On the one hand, companies pursue circular economy goals-such as the use of recycled raw materials-thus highlighting their environmental commitment. On the other hand, such usage may affect the quality and consequently the competitiveness of products. Our study investigates the acknowledgement of these tensions and the strategies adopted by companies to manage them. Using a multiple case study approach, we focus on an Italian sample of three manufacturing sectors: paper production, textile/clothing, and leather. The results show the different defensive and proactive strategies adopted by firms highlighting, in one case, a relevant opportunity exploited by a company considered in the sample. Our paper contributes to the existing knowledge on paradoxical tensions management in companies involved in corporate sustainability inviting scholars towards new research avenues focused on circular economy.
\end{abstract}

\section{KEYWORDS}

industrial symbiosis, paper industrial cluster, paradox theory, recycling, tannery industrial cluster

\section{1 | INTRODUCTION}

Corporate sustainability is the ability of a firm to balance social, economic, and environmental objectives (Kok, Bakker, \& Groenewegen, 2017). This definition shows intrinsic tensions. From a stakeholder's perspective, firms must address the financial needs of stockholders competing in the market, whereas society (customers, regulatory institutions, nongovernmental organizations, etc.) puts pressure on firms to improve their social and environmental performance (Bansal, 2005; Hart \& Milstein, 2003; Jenkins, 2004). From a temporal perspective, the definition requires businesses to address economic, social, and environmental outcomes in the short and the long term, contributing to intertemporal tensions (Slawinski \& Bansal, 2015). These corporate sustainability tensions are often interrelated and persistent and thus can be considered paradoxical (Smith \& Lewis, 2011). Taking a paradox approach helps understand the nature of corporate sustainability tensions, by investigating how organizations acknowledge and manage these tensions when responding to controversial and competing demands (Van der Byl \& Slawinski, 2015). Although this "complex" situation is intrinsically embedded in the management of sustainable businesses, the literature still lacks studies that analyse the tensions and conflicts linked to corporate sustainability (Hahn, Preuss, Pinkse, \& Figge, 2014). In their recent review, Van der Byl and Slawinski (2015) analysed 149 articles published in 15 management journals and observed that only eight took a paradox approach. They found that previous corporate sustainability contributions were mainly focused on win-win (Daddi, Magistrelli, Frey, \& Iraldo, 2011) and trade-off (Brennan and Tennant, 2018) approaches, while omitting any analysis of paradoxical tensions. The authors noted that very few empirical studies have been published in this field, stating that: "paradox articles tend to be conceptual, thus opening up opportunities for empirical work in this area" (Van der Byl \& Slawinski, 2015, p. 55). 
To fill this gap, we examine paradoxical tensions in corporate sustainability by taking an empirical approach in our study. We use a multiple case study with a sample of six firms that are particularly active in the so-called circular economy (CE) and that belong to three key manufacturing industries: paper production, textile/clothing, and leather. The main aim of our study is to analyse the paradoxical tensions resulting from the relation between CE practices and firm competitiveness. Tensions in the relation between corporate social responsibility and competitiveness (Vilanova, Lozano, \& Arenas, 2009; Van der Byl \& Slawinski, 2015) have been identified, so we aim to contribute to this debate by broadening the discussion to include businesses operating in the CE.

The paper is structured as follows. We begin with a brief review of previous studies on paradoxical tensions and corporate sustainability, which leads to a description of the aims of the study and the research questions. The third section provides details on the data and the research method used. We then present and discuss the results before the final section, which concludes.

\section{2 | LITERATURE FRAMEWORK AND RESEARCH QUESTIONS}

\section{1 | Paradox theory and corporate sustainability}

Paradoxical tensions trigger responses that align or create new strategic pathways, which can reframe corporate management and redefine relationships (Stadtler \& Van Wassenhove, 2016), while meeting multiple and competing stakeholders needs (Panayiotou, Putnam, \& Kassinis, 2017). Paradox theory has recently been extended to corporate sustainability as a method of interpreting businesses strategies in cases of controversial demands and pressures (Kolk, 2012; Hahn et al., 2014). Corporate sustainability tensions can appear between system levels and individual levels and can be organizational and systemic, embedding the dynamic process of alternative pathways depending on the sustainability dimensions (Hahn, Pinkse, Preuss, \& Figge, 2015). In corporate sustainability, the paradox perspective highlights "multiple competing sustainable goals simultaneously" (Hahn, Figge, Pinkse, \& Preuss, 2017). Corporate sustainability tensions can surface when at least two of the three pillars of sustainability (economic, social, and environmental) are conflicting, that is, one is positive (increasing), which causes a worsening of another (decreasing). This conflicting relation has recently been analysed in the emerging field of paradoxical tensions in corporate sustainability. For example, livonen (2017) studied the commitment of a leading beverage company to increase its business (a positive economic pillar) and the fact that their product raised obesity levels (a negative social pillar). They thus discussed the defensive organizational strategic response to this paradox between its core business and a societal issue. Stadtler (2017) studied the tensions between social and economic goals and they found that it could be overcome through multiple companies involved in cross-sector social partnerships (CSSP). She observed that in governmental and nongovernmental organization partnerships, managers deliberately leveraged competition through the CSSP design. Similarly, van Hille, de Bakker, Ferguson, and Groenewegen
(2018) focused on paradoxical tensions in CSSP of Dutch sustainable timber sector. The authors highlighted the responses of Forest Stewardship Council Netherlands to face those tensions. Hahn et al. (2014) also focused their study on the relation between the three pillars of sustainability management. They analysed how managers dealt with tensions arising from corporate sustainability in terms of the complex economic, environmental, and social issues. They showed the underlying cognitive determinants of business and the paradox frame that managers adopt to deal with sustainability tensions. According to Ivory and Brooks (2017), the managing of paradoxical tensions in corporate sustainability are through the two pathways of paradoxical resolution and acceptance of paradox. The authors found that companies with "strategic agility" (i.e., strategic sensitivity, collective commitment, and resource fluidity) have an advantage in the managing of the two paradoxical pathways. At a microlevel, Carollo and Guerci (2018) examined how organizational members make sense of paradoxical tensions in relation to their identities as part of the organization when faced with competing demand. Analysing three dichotomous tensions, they found that sustainability identity works at the individual and the organizational level when micropolitical actions are engaged in, to produce management change towards creative and innovative solutions.

\section{2 | Paradoxical tensions and CE}

CE concept states that the economy should shift from a linear model on the basis of production-consumption-disposal towards a circular model, where the reuse of waste is maximized and the use of natural resources reduced (Tukker, 2015). Scholars have recently devoted more attention to $\mathrm{CE}$, and the academic literature reveals active debate at both EU and international levels (McDowall et al., 2017; Merli, Preziosi, \& Acampora, 2017). If CE can be considered a policy concept, the practical application of industrial symbiosis initiatives can be regarded as a method of disseminating it. Thus, industrial symbiosis contributes operationally to the achievement of CE aims, which is mainly focused on energy and by-product exchanges between firms (Chertow, Ashton, \& Espinosa, 2008) and thus achieving economic and environmental goals (Daddi, Nucci, \& Iraldo, 2017). In most cases, the application of a CE and industrial symbiosis means acting to enable resource efficiency. A reduction of the raw materials used (or substituting materials that are less polluting and expensive) can be achieved through more efficient production, and thus, both economic and environmental goals can be realized (Porter \& van der Linde, 1995). This is the classic relation between the environmental and economic pillars, in which both are positive (i.e., a win-win situation; Van der Byl \& Slawinski, 2015). A win-win situation is the most frequently encountered empirical case in the CE context. For example, cement factories can use fly ash to produce cement, which is a secondary raw material and a by-product of coal combustion plants. The fly ash is mixed with other raw materials to produce cement, achieving both economic (fly ash is cheaper than virgin raw materials) and environmental (recovering waste from coal combustion plants) goals. Although this win-win situation often occurs, other CE contexts could create tensions in terms of application and management. The recovery 
of waste and by-products in production processes could increase the environmental commitment of the company (environmental pillar with a positive sign) but can negatively affect the quality or value of the final product, thus reducing the competitiveness of the firm (economic pillar with a negative sign). In this study, we focus on three traditional manufacturing sectors in which we assume these tensions may appear: paper production, textile/clothing, and leather.

Paper production is a relevant sector in terms of economic and environmental aspects and also under the CE perspective is a key sector, due to the widespread use of recycled paper (Monte, Fuente, Blanco, \& Negro, 2009). A niche in the industry produces tissue (handkerchiefs, paper towels, toilet paper, etc.) paper by starting its production from recycled paper instead of virgin cellulose (Paulapuro, 2000). As tissue paper is used for hygienic applications, this aspect may create tensions from the managers' perspective. The production choice could negatively affect competitiveness, when the tissue paper products are compared with those produced by starting from virgin fibres, that is, recycled fibres can be considered a raw material too "dirty" for hygienic uses.

CE initiatives in the textile and clothing industry have a very low level of distribution (Ellen MacArthur Foundation, 2017). Despite this, it exists a market niche that produces textiles starting from recycled wool. As for the paper industry case, we assume that managers will approach corporate sustainability tensions by balancing the need to pursue environmental objectives (increasing the use of recycled wool) and the risk of losing competitiveness, as the clothing sector is not yet ready to accept clothes made with recycled textile (e.g., because often clothes are in contact with the skin).

The last sector we investigate is the leather industry. Our research focuses on tanneries that produce high-quality leather for shoes and bags of luxury fashion brands. Clients apply pressure on tanneries to improve their environmental engagement and to maintain the high quality of the final product. Chrome tanning is one of the main process for leather tanning. High-quality chrome ensures high quality of the final product in the former method. In our study, we will investigate tensions in tanneries that use recycled chrome instead of virgin chrome. According to our theoretical model, this situation could highlight conflicting aims for tanneries: to enable a more sustainable industry (environmental pillar with a positive sign) with the risk to reduce the high quality and high value of their products (economic pillar with a negative sign).

We develop our research questions in these empirical contexts. To develop the first research question, we consider the study of Hahn et al. (2015), who suggested various steps when managing paradoxes in corporate sustainability. The first and most important step is the acknowledgement of conflicting tensions by businesses decision makers, leading to the question:

RQ1: How are tensions acknowledged by organizations in the selected manufacturing sectors?

The same study also states that only once the tensions have been identified and understood can they be managed. The authors identify the second step in the managing of paradoxical tensions as involving the decisions and strategies of managers (Hahn et al., 2015). livonen (2017) classified the responses to paradoxical tensions as proactive or defensive. With proactive strategies firms embrace the tensions and decide on changes triggered by this competing situation, whereas defensive reactions maintain firm legitimacy and produce only slight changes from the past management context. In addition, this double classification has been already adopted also by other scholars in the field of paradox theory (Buysse \& Verbeke, 2003; Ferns, Amaeshi, \& Lambert, 2017; Putnam, Fairhurst, \& Banghart, 2016), so we decided to uniform our approach in the investigation of companies responses to contribute to that literature stream. In specific, we consider strategies that are positive in terms of sustainability (i.e., CE choices) as proactive, whereas the management responses to manage the negative aspect of corporate sustainability tension (i.e., the reduction of competitiveness) are considered defensive. We can thus develop the following further research questions:

RQ2: What are the proactive strategies adopted by the organizations to face tensions?

RQ3: What are the defensive strategies adopted by the organizations to face tensions? In Figure 1, the theoretical approach of the article is illustrated, identifying the CE tensions and including the research questions.

\section{I DATA AND RESEARCH METHOD}

We use the multiple case study research method, as it is particularly suitable for our research. The literature suggests using this method when posing questions related to "how" and "why" (Yin, 2009), which applies to our study. The aim of our research is to understand "how" the tensions affect the selected firms, "how" they are managing them, and "why" the firms decided to adopt those actions to manage them. Second, the method is appropriate when the focus is on a contemporary phenomenon within a real-life context (Yin, 1981), which also applies to our study. We aim to investigate the phenomenon of paradoxical tensions in corporate sustainability by taking an empirical approach, that is, placing the investigation within the "real-life context." Finally, the need to use a multiple instead of a single case study is related to the design of the research. A multiple case study method is suggested when the replication of a phenomenon is investigated, but without any sampling logic (Yin, 2009). The aim of our study is to investigate the decision-making process in managing paradoxical tensions in three different sectors (paper production, textile/clothing, and leather), and thus, we replicate the same research questions in three different industries that may be affected by the same tensions.

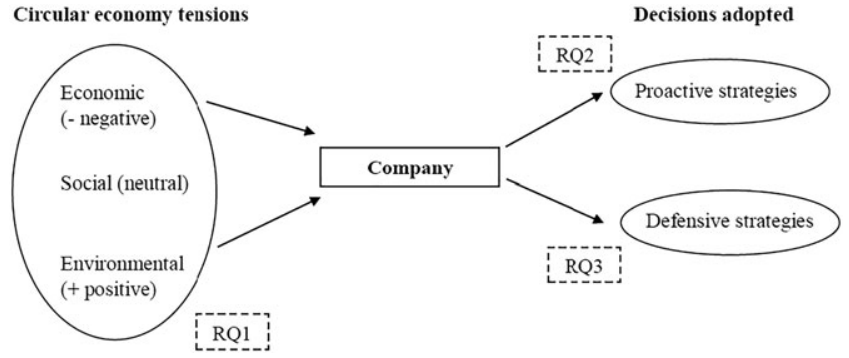

FIGURE 1 Conceptual model and research questions 


\subsection{Data collection and sample}

The geographical context of our research is three industrial clusters in the Tuscany region of Italy. Tuscany is a region with a unique landscape and cultural heritage but also with a strong manufacturing sector, which mainly consists of small and medium enterprises (SMEs). Two companies in our sample are located in the paper industrial cluster of the province of Lucca. This extends over a geographical area of $750 \mathrm{~km}^{2}$. More than 130 paper producing or processing firms (most of which are SMEs) are employing over 5,800 workers (Daddi \& Iraldo, 2016). The companies located in the Lucca cluster manufacture around $20 \%$ of the total Italian paper production, and Italy is in the top five paper-producing countries in Europe (CEPI, 2011).

The textile companies in the sample are located in the textile industrial cluster of the province of Prato. This covers an area of about $700 \mathrm{~km}^{2}$ and includes approximately 8,200 textile companies, the majority of which are SMEs. Over 30,000 workers are employed here (Testa, Nucci, Iraldo, Appolloni, \& Daddi, 2017). Recycled wool is a traditional production of the district, and carding is a typical method of processing the fibres.

The yarns and fabrics are produced by reusing fibres obtained from recycling old knitted clothing and from cuttings of new fabrics used in the garment industry (Testa et al., 2017).

The third geographical context is the tannery industrial cluster of Santa Croce Sull'Arno in the province of Pisa. The cluster covers an area of about $240 \mathrm{~km}^{2}$ and includes six municipalities. (Daddi, Nucci, Iraldo, \& Testa, 2016). This tannery cluster is the largest in Italy, providing $35 \%$ of the Italian production of tanned leather and $98 \%$ of sole leather. Italy has also a significant position in the EU production of finished leather and accounts for about $66 \%$ of the total EU production (UNIC, 2015). The cluster is very active in the CE and several of the companies that use chrome for the tanning process recover and reuse it via a local chromium recovery plant (Daddi et al., 2017).

From these three territorial contexts, we sampled six firms, two per each investigated industries. We contacted local stakeholders (e.g., local industrial associations) to identify the companies that may have the features required for the study, that is, application of $\mathrm{CE}$ and the need to keep high the competitiveness of their products. Table 1 indicates the characteristics of the companies involved in the study.

Most of the interviewed companies of our case studies were SMEs. This was not a voluntary choice but a key characteristic of Italian manufacturing sectors and of the selected industrial clusters.
In four out of six cases, we interviewed the owners of the firms who were also the CEOs. For paper mill \#1, we interviewed the environmental manager, as the firm is managed as a family business, and he had discussed the topics in our interview many times with the entrepreneur. For the second paper mill, we interviewed the communication manager, who was very well informed about sustainability and competitiveness, for both the targeted plant and the group as a whole.

To increase the reliability of our multiple case study, we developed a "case study protocol" (Yin, 2009). The interviews were conducted during the first months of 2018 by in-depth face-to-face meetings with the interviewees. The interviews lasted about $2 \mathrm{hr}$. Before the interviews, we guaranteed the interviewees anonymity in our use of the collected information. During our introduction, we provided information about the study but avoided explicitly mentioning the term "paradoxical tensions" in order to avoid social desirability bias. The interviews were recorded, and we observed the following rules: ask one question at a time, remain as neutral as possible, and be careful about our appearance when note taking (Leech, 2002). All the interviews were transcribed. Among the questions included in the protocol were, for example, "your company produces final products starting from recycled material, could you please describe this strategic choice?" in the case of paper production, "Your product should be used for hygienic purposes, do you think that this choice can affect your competitiveness?" "According to your opinion your customers award more your choice to support CE or they are diffident about the quality of the final products?" The protocol was aimed only at providing a reference to conduct the interview. Often, the interviewees anticipated the questions about the decision-making process, providing examples of actions and strategies during the investigation that acknowledged the tension.

\section{4 | RESULTS}

\subsection{Acknowledgement of tensions}

The notion of corporate sustainability intrinsically encompasses interrelated yet competing demands among its three pillars and across time. The acceptance and management of opposing goals that create tensions may also reveal innovative solutions and previously untapped possibilities that help address sustainability challenges (Brown, 2009; Byrch, Milne, Morgan, \& Kearins, 2015). In our cases, we investigated

TABLE 1 Sample features

\begin{tabular}{|c|c|c|c|c|c|}
\hline Firm & Location & Product & $\begin{array}{l}\text { Turnover } 2017 \\
\text { (k euros) }\end{array}$ & Employees & Position of interviewee \\
\hline Paper \#1 & Industrial cluster of Lucca & Tissue paper from recycled paper & 15,274 & $\sim 50$ & Environmental Manager \\
\hline Paper \#2 & Industrial cluster of Lucca & Tissue paper from recycled paper & 365,485 & $\begin{array}{l}\sim 120 \text { (the plant) } \\
\sim 1,338 \text { (the group) }\end{array}$ & $\begin{array}{l}\text { Communication } \\
\text { Manager }\end{array}$ \\
\hline Textile \#1 & Industrial cluster of Prato & Textile from recycled fibres & 8,498 & $\sim 30$ & Owner \\
\hline Textile \#2 & Industrial cluster of Prato & Textile from recycled fibres & 11,739 & $\sim 10$ & Owner \\
\hline Leather \#1 & $\begin{array}{l}\text { Industrial cluster of Santa } \\
\text { Croce Sull'Arno }\end{array}$ & Finished leather using recovered chrome & 48,843 & $\sim 86$ & Owner \\
\hline Leather \#2 & Santa Croce Sull'Arno & Finished leather using recovered chrome & 20,017 & $\sim 55$ & Owner \\
\hline
\end{tabular}


the existence of paradoxical tensions between the environmental benefits arising from CE activities, such as using recycled inputs and the consequent potential loss in competitiveness due to using recycled materials in specific products, which consumers may perceive as of inferior quality. As the first aim of our study, we investigated these assumed tensions in the three industries of our sample.

In the paper sector, we asked whether using waste paper as a secondary raw material (i.e., waste paper) to produce tissue paper for kitchens or restrooms would undermine the product competitiveness if compared with tissue paper produced by using virgin fibres. Indeed, the manager of the first paper mill interviewed confirmed our assumption:

This is a topic we often discuss internally among managers. We are aware of this controversy and all companies operating in this sector face the same problem. We know that consumers could be generally concerned about using tissue paper for personal and hygienic use made from waste paper, and this is a misconception not easy to overcome (Paper mill \#1).

The first paper mill fully confirmed our hypothesis, as the use of recycled paper for tissue products could create tensions in terms of the company's strategic management. The tension is acknowledged, which leads to the acceptance of RQ1.

As for paper mill \#2, they first denied the existence of any tensions and claimed their pride for producing a tissue paper of high quality whilst environmentally friendly. Yet, they subsequently revealed that this was the result of an investment that they made to avoid the tension between quality and using recycled inputs.

We use recycled pulp to be environmentally-friendly and this reflects our company values. At the same time, we manage to only produce and sell tissue paper of high quality. Considering tissue paper three key characteristics (tenderness, resistance, and capacity of absorption of liquids), we judge the of our final product quality and competitiveness fully comparable with products produced from virgin cellulose (Paper mill \#2).

To investigate further, we asked the interviewee of paper mill \#2 whether they had taken any action to improve the quality of their final product, to remain environmentally friendly while increasing their competitiveness. Through his answer, he indirectly confirmed the tension described by paper mill \#1:

In these last years, we invested $€ 12$ million in research and development to increase the quality of recycled paper as raw material. The lower and lower quality of the paper we receive from municipal separate waste collection is an important issue that can affect the competitiveness of our product. It was quite an investment, but with the results we obtained, it is still paying off (Paper mill \#2).

The need to pursue improvement in the quality of the waste paper used as a raw material indirectly confirms the presence of a tension between being environmentally friendly and competitive in the market by producing a quality product. For this reason, we argue that RQ1 is confirmed. In addition, we must consider that here we were interviewing a communication manager of a company leader in tissue paper produced from recycled material, so we expected his initial reluctance to admit any tension.

In the textile and clothing sector, neither company admitted the presence of any tension between being environmentally friendly and remaining competitive by producing quality textiles and fabrics from recycled inputs. Both companies are family businesses with a long standing tradition in the textile district of Prato, which may influence the extent of their disclosure, making them more hesitant to admit that their product may be less competitive in the market.

Our family business puts environmental sustainability at the core of its activities and since our inception in 1951 we have used recycled wool in our productive cycle ensuring the quality of our products (Textile and clothing \#1).

We do not feel any discrepancy in being environmentallyfriendly and staying competitive in the market. We achieve successfully both goals by using recycled wool for our fabrics, which are at the basis of our company (Textile and clothing \#2).

As expected, the two interviewees had some difficulties in admitting that their efforts to be green could diminish the competitiveness of their products in the market. However, we pressed this point by asking indirect questions about their sector rather than their specific business. Through this approach, both companies indirectly confirmed our assumptions. They argued that although circularity in production is encouraged by European and national laws, in Italy there is a ministerial decree (no. 264/2016) that imposes a requirement for hygienic sanitization on their products. We also find that the existence of tensions is indirectly confirmed by a regulatory act. If a national law imposes additional actions to satisfy the hygienic performance of a product produced by using recycled wool, it could indirectly confirm that the competitiveness of this product is lower due to hygienic concerns, thus creating corporate sustainability tensions.

Finally, clear results emerged from the investigation of tensions within the leather sector. The first tannery interviewed acknowledged the existence of conflicting demands related to the CE in the leather sector.

The use of recovered chrome for our tannery, it is convenient both from an environmental and economical point of view. Yes, using recycled chrome influences the quality of tanned hides. It may be a problem for those tanneries that serve the medium-high share of the market, but it is not an issue for us since we produce low quality finished leather (Tannery \#1).

We interviewed a second tannery that tan hides for premium fashion brands. Again, the interviewee had no hesitation in declaring a tension between pursuing environmental objectives and achieving high quality products: 
Of course, you notice the difference when you tan hides with recycled chrome as opposed to using pure chrome, its undeniable! By using pure chrome, you achieve a superior product. Our clients chose us for our high quality leather and attention to details. They want quality and we cannot disappoint them. That is why we only employ pure chrome and the recovered chrome we have to take back from the recovery plant of the industrial district we decided to resell to other tanneries (Tannery \#2).

This difference between the two tanneries is mainly due to the different type of leather and market they serve, as emerged from the interviews. Tannery \#1 does not experience any tension, as it uses either recycled or pure chrome with no difference in the final product, as it serves the lower end of the market. We could thus identify it as a mistake in the sampling procedure of our study, because as we stated in the literature review section, our aim was to interview companies that were suppliers of luxury brands in which we supposed higher tensions existed.

In contrast, Tannery \#2 fully complies with the targeted sample, as it produces high-quality leather for luxury brands. We note that according to specific local regulations of the tannery district of $\mathrm{S}$. Croce sull'Arno, all the tanneries must send their chrome to the recovery plant and then they are obliged to take the recovered chrome back. The tension between using recycled chrome and remaining competitive is thus considered by the company too high, as it cannot be managed. They decide to avoid this by selling the recovered chrome to tanneries that produce low-quality leather. This choice does not indicate either defensive or proactive strategies. The management of the tension is avoided, so we can identify this action as the adoption of an "escape strategy."

In Table 2, we report whether the interviewees admitted facing competing demands in managing their companies by involving the $\mathrm{CE}$.

Although both paper mill \#1 and tannery \#2 openly acknowledged the presence of conflicting pressures, tannery \#2 also admitted to escaping such pressures, thus avoiding any increase in tension. The second paper mill interviewed and the two companies in the textile and clothing sector were at first reluctant to openly admit that using recycled inputs may affect the quality of their final product, resulting in diminished competitiveness. Finally, no tension was felt by the interviewee in tannery \#1.

We do not further examine the companies working in the leather sector in Section 4.2, even if either they are not subject to our investigated tensions (\#1), or they avoided it altogether (\#2).

TABLE 2 Acknowledgement of tension

\begin{tabular}{|ll}
\hline & \multicolumn{1}{c}{ Acknowledgement of tension } \\
\hline Paper mill \#1 & Openly acknowledged \\
\hline Paper mill \#2 & Reluctant to admit/Indirectly acknowledged \\
\hline Textile and Clothing \#1 & Reluctant to admit/Indirectly acknowledged \\
\hline Textile and Clothing \#2 & Reluctant to admit/Indirectly acknowledged \\
\hline Tannery \#1 & Openly Acknowledged but not felt \\
\hline Tannery \#2 & Openly Acknowledged and avoided/escaped \\
\hline
\end{tabular}

\section{2 | Defensive strategies adoption}

In addressing our research questions 2 and 3, during the interviews, we investigated the proactive and defensive strategies and actions that the selected sample of companies adopted to manage the paradoxical tensions. Recalling Section 2.2, we labelled the actions primarily aimed at promoting environmental engagement in the CE as proactive strategies, and the strategies aimed at reducing the "negative" sign of the economic pillar of corporate sustainability, that is, increasing the firm competitiveness, as defensive. In this section, we focus on defensive strategies adopted by our sample. A kind of actions commonly adopted by our sample of paper sector refers to technological answers adopted to face the tension. The two paper mills interviewed approached their technological assets differently. Paper mill \#1 improved competitiveness by adding virgin fibres to recycled inputs, whereas paper mill \#2 invested in using higher quality recycled inputs to become more competitive.

We invested in specific machinery to make tissue from recycled material and achieve superior quality, satisfying our Italian consumers (Paper mill \#1).

In the last years we invested 12 million of euros in a new process we patented. This new process allows us to recover paper from Tetra Pak packaging. The cellulose fibres of Tetra Pak packaging were available in good quantities in the market to justify the investment. Before our process Tetra Pak packaging in Italy was disposed to landfill since it contains not only paper but also aluminium and polyethylene (Paper mill \#2).

What was described by paper mill \#2 is particularly interesting. The need of the company to manage the negative sign of the tension (due to the reduction of the quality of recycled paper obtained by the municipal separate collection) forced them to make a strong investment. They identified the packaging of the food multinational company Tetra Pak (the packages used to contain food and beverages) as a good source of paper with similar characteristics to the virgin fibres. The strategy then allowed them to not only face the challenge posed by the tension but also to gain additional opportunities and to identify innovative solutions to address the sustainability challenge as observed in previous studies on tensions management (Brown, 2009; Byrch et al., 2015).

As defensive responses, the textile and clothing firms did not adopt any technological actions; instead, they focused on the selection and management of recycled raw materials. As confirmed by recent studies, the quality of secondary raw materials is an important barrier for the CE uptake (Steinmann, Huijbregts, \& Reijnders, 2019). In our sample, the selection of recycled raw materials is also a key topic in the management of the tensions we are investigating. This mainly affects the quality of products, thus acting as a defensive strategy. In terms of the importance of the quality of waste paper used to produce tissue paper, as discussed in the previous lines, we classify this for paper mill \#2 as a technological response, even if it referred to the topic of recycled raw material. In the textile sector, we found mainly defensive strategies as responses. 
To increase the quality of our product we invest a huge effort in the sorting of recycled fabrics to be used as raw material. For example the colour separation is relevant from a production process point of view (Textile and clothing \#1).

We assure our customers of the traceability of the recycled materials we used as input in the production process (Textile and clothing \#2).

Company \#1 increases the quality of their products by assuring a high level of sorting of the recycled raw materials. The strategy adopted by company \#2 aims to trace the origin of the secondary raw materials used in the production process. This is classified as defensive, as according to the interviewee, it enables the company to increase the trust of their customers towards a production that uses recycled fabrics.

\section{3 | Proactive strategies adoption}

Our sample adopted also proactive strategies, that is, actions to manage the tension aimed to valorize their commitment towards CE. The kind of proactive responses adopted are common for both sectors and refers to third party environmental certifications. Third-party certifications are significant for Italian firms. Italy is a country with a high level of process and product environmental certification (Daddi, Frey, De Giacomo, Testa, \& Iraldo, 2015). Environmental certificates are clearly part of a proactive strategy, as they promote the company's environmental commitment, but we also investigated the presence of certifications to highlight the quality of the product, that is, classified as defensive strategies.

We are EMAS (Eco-management and Audit Scheme) registered to demonstrate the attention we devote to the environmental impacts of our processes and to communicate transparently our commitment toward environmental protection (Paper mill \#1).

We are the first paper company that obtained the European Ecolabel for tissue products, confirming our environmental commitment (Paper mill \#2).

Paper mills have obtained relevant and well-known environmental certifications. EMAS refers to the production process, whereas the
European Ecolabel refers to the sustainability of products. Both firms demonstrate to believe in third certifications as a mean to highlight their engagement in corporate sustainability. Similarly, also the sample of textile and clothing companies look at the environmental certifications ad proactive responses.

We obtained the Global Recycling Standard certification
to demonstrate to our clients our engagement in
environmental and social issues (Textile and clothing \#1).

We are part of the DETOX programme, working with Greenpeace and other stakeholders to demonstrate the decrease of the quantity of toxic substances in our products (Textile and clothing \#2).

Textile company \#1 obtained the Global Recycling Standard certification, which is intended for companies making and/or selling products with recycled content. The standard applies to the full supply chain and addresses traceability, environmental principles, social requirements, and labelling. The involvement of textile company \#2 in the DETOX programme is the last proactive action in our sample. This could also be classified as defensive because this programme, even if conceived on a voluntary basis, is more related to proving the absence of certain dangerous substances in the products than to confirming the environmental commitment of companies.

Another field of action we identified was related to external communication. The factories of our sample have been both proactive (aimed at communicating the environmental commitment to pursue CE goals) and defensive (aimed at boosting the qualitative features of the products).

Paper mill \#1 stated that the domestic market was more sensitive to the quality of the tissue paper produced with recycled fibres, whereas other markets (such as Germany) were more positive towards the environmental commitment of the firm. Paper mill \#2 instead highlights the relevance of their proactive communication actions aimed at leveraging the results of the new technology described in the previous section (Table 3).

\section{5 | DISCUSSION AND CONCLUSIONS}

The integrative view on corporate sustainability proposes that firms should address economic, environmental, and social aspects

TABLE 3 External communication strategies adopted to manage the tension referred to both proactive as well as defensive strategies

\begin{tabular}{|c|c|c|}
\hline & Defensive strategies & Proactive strategies \\
\hline Paper mill \#1 & $\begin{array}{l}\text { "In Italy there is a high culture related to the quality of paper. } \\
\text { In this market our communication is mainly aimed at } \\
\text { communicating that even if our paper is produced with } \\
\text { recycled paper, it is of good quality" }\end{array}$ & $\begin{array}{l}\text { "The external communication toward certain foreign } \\
\text { market such as Germany is more oriented to highlight } \\
\text { the environmental benefits of producing tissue paper } \\
\text { starting from recycled fibres" }\end{array}$ \\
\hline Paper mill \#2 & & $\begin{array}{l}\text { "Since the new technology we adopt allowed us to achieve } \\
\text { relevant environmental objectives with the recycling of } \\
\text { Tetra Pak bricks, we are adopting a strong external } \\
\text { communication strategy based on this aspect" }\end{array}$ \\
\hline $\begin{array}{l}\text { Textile and } \\
\text { clothing \#1 }\end{array}$ & $\begin{array}{l}\text { "Our customers need to know better the quality of the } \\
\text { products produced with recycled wool. We have } \\
\text { frequent visits in our plant on this issue carried out } \\
\text { by our main important customers such as Benetton" }\end{array}$ & $\begin{array}{l}\text { "We communicate our environmental commitment externally. } \\
\text { We don't only communicate the fact that we use recycled } \\
\text { textiles as raw materials but also that a process with such } \\
\text { raw materials need less use of chemicals and water" }\end{array}$ \\
\hline
\end{tabular}


simultaneously without, a priori, emphasizing one aspect over another even if this entails tensions and conflicts (Hahn et al., 2015). Our study highlights that these tensions are reluctantly acknowledged by companies' managers, because they impact on the core business of the company, such as the competitiveness of products. The strategies used to deal with these paradoxical tensions range from proactive and defensive to total avoidance, as evidences found in other studies (Jarzabkowski, Lê, \& Van de Ven, 2013).

In our cases, we encountered the "Paradox of Organizing" (Lewis, 2000), because companies try to equilibrate opposing forces that encourage commitment, trust, and creativity, while maintaining efficiency. Companies that decided to tackle their paradoxical tensions were lead to a "management shift," opening up the way towards new sustainable opportunities. In that sense, part of the investigated companies destroyed corporate past understandings and practices to construct new and more complex frames of references in terms of sustainability. Differently to what Lewis (2000) argued, companies in our sample dealt with paradoxical tensions (economic vs. environmental) according to both learning and organizing process. The aim of our study was to examine the paradoxical tensions in corporate sustainability, by linking the relation between the CE and a firm's competitiveness. We investigated how the tensions were acknowledged by six organizations from three manufacturing sectors (paper mills, textile and clothing, and tanneries) and which strategies (defensive and proactive) were used to tackle them.

The performing paradoxes tensions arise between the potential negative economic outcomes of companies adopting positive environmental solutions in their usual business practice and competitiveness (Smith \& Lewis, 2011). For instance, there is a possible negative effect on the image and product quality of a high-end, luxury leather producer when recovered or recycled materials are used. An initial significant result of our paper is the confirmation that the supposed kinds of performing paradoxes tensions exist. Apparently, these performing paradoxical tensions are instrumentally justified by corporate sustainability (Hahn et al., 2017), but through a more detailed analysis they are normatively justified as well because of lack of integration between the microlevel and macrolevel of knowledge of sustainability (Dyllick \& Muff, 2016). This lack of integration leads to incremental improvements of sustainability by business-as-usual model, but the corporate continues to contribute to environmental degradation (Landrum \& Ohsowski, 2018); this paradox is normatively accepted, although the strong sustainability is claimed by society. Considering high value products (i.e., finished leather for luxury brands) or hygienic products (i.e., tissue paper), the use of secondary raw materials could influence the "appeal" of these products, thus creating paradoxical tensions. This first finding is confirmed in the literature. For instance, Achabou and Dekhili (2013) conducted an empirical study regarding French luxury clothing and found that incorporating recycled materials in such goods negatively affects consumer preferences. Consumers were aware of the benefits of recycling to the environment and did not regard this practice unfavourably; however, a rejection of the use of recycled materials in luxury products was reported.
Our data suggest that environmentally pressured industries are faced with tensions, which can be regarded as paradoxical given that the elements are characterized by interdependencies and at the same time contradictions. Proactive but also defensive strategies were used to tackle these contradictions as other studies show (Jarzabkowski et al., 2013). Interestingly, such tensions, although present and acknowledged, were not always explicitly admitted because they are still latent (Smith \& Lewis, 2011). From the analysed cases, an "indirect" admission was mostly elicited, and several companies were classified according to our first research question as "reluctant to admit." In this last case, we confirm the proposed proposition by Smith and Lewis (2011, p. 391) "Latent paradoxical tensions become salient as actors apply paradoxical cognition."

Although the interviews with tanneries were not considered in the investigation of the adopted strategies, they provided important insights. First, they confirmed one of our hypotheses: only certain products, despite belonging to the same industry, highlighted the tensions between the $\mathrm{CE}$ and competitiveness, which is choosing between pro-active or defensive strategy (Jarzabkowski et al., 2013). This was the case of tannery \#1, which works at the lower end of the market, and the use of recovered or recycled raw material has positive environmental benefits without influencing competitiveness. In this case, not only the sector but also the market positioning (costbased) determined the acceptance and resolution of the performing paradoxical tensions. This finding supports our normative justification beyond the corporate field through the paradox lens, as discussed above (Hahn et al., 2017), because the market is accepting this performing paradox tension as well.

Our study also contributes and advances to the findings of Slawinski and Bansal (2015) suggesting that companies focusing on defensive strategies suffer from temporal myopia, because they focus on short-term efficiency measures. On the other hand, proactive strategies can be a smart way to tackle long-term and complex paradoxical tensions such as the ones related to sustainability.

We have also unveiled a new strategy to deal with tensions on the basis of the organizational behaviour of tannery \#2, here referred to as the "escape strategy." This company was well aware of the performing paradoxes tensions but had sought an alternative strategy to avoid it. In this case, they used pure raw material (chrome) and resold the recycled chrome it was obliged to use according to the industrial cluster rules. This shows a combination of a defensive strategy towards a regulatory factor, and a proactive strategy, considering its market positioning. Smith and Lewis (2011) argues that splitting and integrating of paradoxical tensions lead to sustainability, although our study supports an environmental factor as government regulation to deal with paradox. Further research is needed to better understand this case because the current theoretical context lacks contributions that describe the adoption of escape strategies to avoid paradoxical tensions.

Although indirectly, the companies in our sample adopted more proactive than defensive strategies to deal with performing paradoxical tensions (economic vs. social and environmental). From the categories we identified, external communication and third-party certification was found to be common successful strategies. These management strategies deal with the performing paradox tensions 
(economic vs. environmental) and shed light on gap in the academy and business world about the strategies for paradoxes (Jarzabkowski et al., 2013). The decision of paper mill \#2 to adopt a strong technological innovation to manage the tension is another significant result of our paper. It confirms, as observed by some of the literature on paradoxical tensions, that these competing demands can often shed light on real opportunities, which may be hidden in cases where there are no tensions. As livonen (2017) highlights, it is very challenging for controversial industries (as the ones in our study) to adopt an integrative approach to sustainability, because the tensions would eventually lead them to cease their existence. Such industries, their companies, and many others are certainly not willing to close up their business or to engage in radical changes but nevertheless forced to tackle external and internal tensions. CE can be a way to deal with these paradoxical issues, because the power of circling longer, cascading use, and designing products with sustainable inputs can ultimately lead to a combined solution fostering the desired dynamic equilibrium (Smith \& Lewis, 2011).

\section{1 | Managerial implications}

In terms of management implications, our findings provide data that could be used by managers who face similar situations related to $\mathrm{CE}$ engagement and competitiveness. First, in some cases, the management of tensions can stimulate original strategies and lead to new and unexpected opportunities. This is confirmed by the case of paper mill \#2. Second, according to our sample, some strategies adopted to manage tensions are exclusively defensive or proactive. For example, strategies aimed at selecting and managing recycled raw materials are mainly defensive, whereas the adoption of voluntary certifications is mainly proactive. Innovative managers thus need to find new solutions and strategies, for example, by adopting third party certifications also from a defensive perspective (i.e., contrasting the reduction of competitiveness), which entails providing evidence that the quality of their products is totally comparable with the competitors' products. The manager of paper mill \#2 referred to the quality of their tissue paper in terms of "three key characteristics (softness, resistance, and capacity to absorb liquids), whose quality and competitiveness we believe is fully comparable with products produced from virgin cellulose." With a technical verification/certification, this statement could achieve a higher credibility and could represent an effective defensive strategy. Third, the frequent external communication strategies seem to confirm the relevance of customers' awareness regarding the quality of products made from secondary raw materials and companies' commitment to CE initiatives. Managers should bear in mind the importance of a clear and transparent communication in these fields. Finally, a key aspect that can create tensions in the CE is the quality of the recycled raw materials. All the investigated sectors are affected by this aspect, which can negatively influence their competitiveness. It is fundamental to obtain high-quality recycled raw materials in order to lessen the tensions. This also represents an important policy implication. Policy makers should facilitate the presence on the market of good-quality recycled materials in order to remove the barriers to an effective uptake of the CE.

\subsection{Limitations and future research avenues}

Our paper includes also some limitations. Although it is likely that similar tensions are also experienced by other companies in the investigated industries, our findings cannot necessarily be extended to other such industries or to other manufacturing sectors operating with recycled raw materials. Our sampling procedure may also represent a limitation. Tannery \#1 was wrongly selected. Although the interview helped us to understand the tensions in the leather industry, it was not used to investigate RQ2 and RQ3. The same applies to tannery \#2. Its escape strategy impeded us from understanding how they manage tensions in the leather sector. A second limitation is linkable to the number of managers interviewed. Also, because our sample was constituted by small companies, we interviewed only one manager per company. In bigger companies, to interview different managers could help the identification of tensions and strategies. Finally, we identified the use of secondary raw materials as a decision that positively influences the environmental commitment (environmental pillar with positive sign) and negatively influences the competitiveness (economic pillar with negative sign). We are fully aware that this decision, in the selected industries, often also involves a lower cost of the raw materials, that is, the possibility of selling the final product at a lower price. This positive price effect could compensate for the negative effect on the competitiveness caused by the reduction in the quality of final products. Future research could investigate how this aspect influences the tensions described in our paper. An additional future research avenue would be to consider other industrial sectors that may be affected by the same tensions, such as the food sector. Several protein-based by-products are recovered in the food sector, and in our opinion, this may lead to similar tensions investigated in this paper.

\section{ORCID}

Tiberio Daddi (1D https://orcid.org/0000-0002-9716-3388

\section{REFERENCES}

Achabou, M. A., \& Dekhili, S. (2013). Luxury and sustainable development: Is there a match? Journal of Business Research, 66(10), 1896-1903. https://doi.org/10.1016/j.jbusres.2013.02.011

Bansal, P. (2005). Evolving sustainably: A longitudinal study of corporate sustainable development. Strategic Management Journal, 26(3), 197-218. https://doi.org/10.1002/smj.441

Brennan, G., \& Tennant, M. (2018). Sustainable value and trade-offs: Exploring situational logics and power relations in a UK brewery's malt supply network business model. Business Strategy and the Environment, 27(5), 621-630.

Brown, J. (2009). Democracy, sustainability and dialogic accounting technologies: Taking pluralism seriously. Critical Perspectives on Accounting, 20(3), 313-342. https://doi.org/10.1016/j.cpa.2008.08.002

Buysse, K., \& Verbeke, A. (2003). Proactive environmental strategies: A stakeholder management perspective. Strategic Management Journal, 24(5), 453-470. https://doi.org/10.1002/smj.299

Byrch, C., Milne, M. J., Morgan, R., \& Kearins, K. (2015). Seeds of hope? Exploring business actors' diverse understandings of sustainable development. Accounting, Auditing \& Accountability Journal, 28(5), 671-705. https://doi.org/10.1108/AAAJ-08-2013-1438

Carollo, L., \& Guerci, M. (2018). 'Activists in a Suit': Paradoxes and Metaphors in Sustainability Managers' Identity Work. Journal of Business Ethics, 148(2), 249-268. 
CEPI (2011). Sustainability report 2011. Brussels: CEPI.

Chertow, M. R., Ashton, W. S., \& Espinosa, J. C. (2008). Industrial symbiosis in Puerto Rico: Environmentally related agglomeration economies. Regional Studies, 42, 1299-1312. https://doi.org/10.1080/ 00343400701874123

Daddi, T., Frey, M., De Giacomo, M. R., Testa, F., \& Iraldo, F. (2015). Macroeconomic and development indexes and ISO14001 certificates: A cross national analysis. Journal of Cleaner Production, 108, 1239-1248. https://doi.org/10.1016/j.jclepro.2015.06.091

Daddi, T., \& Iraldo, F. (2016). The effectiveness of cluster approach to improve environmental corporate performance in an industrial district of SMEs: A case study. International Journal of Sustainable Development and World Ecology, 23(2), 163-173. https://doi.org/10.1080/ 13504509.2015.1106988

Daddi, T., Magistrelli, M., Frey, M., \& Iraldo, F. (2011). Do environmental management systems improve environmental performance? Empirical evidence from Italian companies. Environment, Development and Sustainability, 13(5), 845-862. https://doi.org/10.1007/s10668-0119294-8

Daddi, T., Nucci, B., \& Iraldo, F. (2017). Using Life Cycle Assessment (LCA) to measure the environmental benefits of industrial symbiosis in an industrial cluster of SMEs. Journal of Cleaner Production, 147, 157-164. https://doi.org/10.1016/j.jclepro.2017.01.090

Daddi, T., Nucci, B., Iraldo, F., \& Testa, F. (2016). Enhancing the adoption of life cycle assessment by small and medium enterprises grouped in an industrial cluster: A case study of the tanning cluster in Tuscany (Italy). Journal of Industrial Ecology, 20(5), 1199-1211. https://doi.org/ 10.1111/jiec.12379

Dyllick, T., \& Muff, K. (2016). Clarifying the meaning of sustainable business: Introducing a typology from business-as-usual to true business sustainability. Organization \& Environment, 29(2), 156-174. https:// doi.org/10.1177/1086026615575176

Ellen McArthur Foundation, 2017. A new textiles economy: Redesigning fashion's future, (accessed from: http://www. ellenmacarthurfoundation.org/publications).

Ferns, G., Amaeshi, K., \& Lambert, A. (2017). Drilling their own graves: How the European oil and gas supermajors avoid sustainability tensions through mythmaking. Journal of Business Ethics, 1-31. https:// doi.org/10.1007/s10551-017-3733-x

Hahn, T., Figge, F., Pinkse, J., \& Preuss, L. (2017). A paradox perspective on corporate sustainability: Descriptive, instrumental, and normative aspects. Journal of Business Ethics, 148, 235-248.

Hahn, T., Pinkse, J., Preuss, L., \& Figge, F. (2015). Tensions in corporate sustainability: Towards an integrative framework. Journal of Business Ethics, 127(2), 297-316. https://doi.org/10.1007/s10551-014-2047-5

Hahn, T., Preuss, L., Pinkse, J., \& Figge, F. (2014). Cognitive frames in corporate sustainability: Managerial sensemaking with paradoxical and business case frames. The Academy of Management Review, 39(4), 463-487. https://doi.org/10.5465/amr.2012.0341.

Hart, S. L., \& Milstein, M. B. (2003). Creating sustainable value. The Academy of Management Executive, 17(2), 56-67.

van Hille, I., de Bakker, F. G., Ferguson, J. E., \& Groenewegen, P. (2018). Navigating tensions in a cross-sector social partnership: How a convener drives change for sustainability. Corporate Social Responsibility and Environmental Management, https://doi.org/10.1002/csr.1684

livonen, K. (2017). Defensive responses to strategic sustainability paradoxes-Have your coke and drink it too! Journal of Business Ethics https://doi.org/10.1007/s10551-017-3580-9, 148, 309-327.

Ivory, S. B., \& Brooks, S. B. (2017). Managing corporate sustainability with a paradoxical lens: Lessons from strategic agility. Journal of Business Ethics https://doi.org/10.1007/s10551-017-3583-6, 148, 347-361.

Jarzabkowski, P., Lê, J. K., \& Van de Ven, A. H. (2013). Responding to competing strategic demands: How organizing, belonging, and performing paradoxes coevolve. Strategic Organization, 11(3), 245-280. https:// doi.org/10.1177/1476127013481016
Jenkins, H. (2004). Corporate social responsibility and the mining industry: Conflicts and constructs. Corporate Social Responsibility and Environmental Management, 11(1), 23-34. https://doi.org/10.1002/csr.50

Kok, A. M., de Bakker, F. G., \& Groenewegen, P. (2017). Sustainability struggles: Conflicting cultures and incompatible logics. Business \& Society, 2017, 1-37. 0007650317703644

Kolk, A. (2012). Towards a sustainable coffee market: Paradoxes faced by a multinational company. Corporate Social Responsibility and Environmental Management, 19(2), 79-89. https://doi.org/10.1002/csr.289

Landrum, N. E., \& Ohsowski, B. (2018). Identifying worldviews on corporate sustainability: A content analysis of corporate sustainability reports. Business Strategy and the Environment, 27(1), 128-151. https://doi.org/10.1002/bse.1989

Leech, B. L. (2002). Asking questions: Techniques for semistructured interviews. PS: Political Science \& Politics, 35(4), 665-668.

Lewis, M. W. (2000). Exploring paradox: Toward a more comprehensive guide. Academy of Management Review, 25(4), 760-776. https://doi. org/10.5465/amr.2000.3707712

McDowall, W., Geng, Y., Huang, B., Barteková, E., Bleischwitz, R., Türkeli, S., ... Doménech, T. (2017). Circular economy policies in China and Europe. Journal of Industrial Ecology, 21, 651-661. https://doi.org/ 10.1111/jiec.12597

Merli, R., Preziosi, M., \& Acampora, A. (2017). How do scholars approach the circular economy? A systematic literature review. Journal of Cleaner Production, 178(20), 703-722.

Monte, M. C., Fuente, E., Blanco, A., \& Negro, C. (2009). Waste management from pulp and paper production in the European Union. Waste Management, 29(1), 293-308. https://doi.org/10.1016/j. wasman.2008.02.002

Panayiotou, A., Putnam L. L., \& Kassinis G. (2017). Generating tensions: A multilevel, process analysis of organizational change. Strategic Organization ".", https://doi.org/10.1177/1476127017734446.

Paulapuro, H. (2000). Paper and board grades, papermaking science and technology, book (p. 18). Finland: Published in cooperation with the Finnish Paper Engineers' Association and TAPPI. Jyväskylä.

Porter, M., \& van der Linde, C. (1995). Toward a new conception of the environment competitiveness relationship. Journal of Economic Perspectives, 9(4), 97-118. https://doi.org/10.1257/jep.9.4.97

Putnam, L. L., Fairhurst, G. T., \& Banghart, S. (2016). Contradictions, dialectics, and paradoxes in organizations: A constitutive approach. The Academy of Management Annals, 10(1), 65-171.

Slawinski, N., \& Bansal, P. (2015). Short on time: Intertemporal tensions in business sustainability. Organization Science, 26(2), 531-549. https:// doi.org/10.1287/orsc.2014.0960

Smith, W. K., \& Lewis, M. (2011). Toward a theory of paradox: A dynamic equilibrium model of organizing. Academy of Management Review, 36, 381-403.

Stadtler, L. (2017). Tightrope walking: Navigating competition in multicompany cross-sector social partnerships. Journal of Business Ethics https://doi.org/10.1007/s10551-017-3579-2, 148, 329-345.

Stadtler, L., \& Van Wassenhove, L. N. (2016). Coopetition as a paradox: Integrative approaches in a multi-company, cross-sector partnership. Organization Studies, 37(5), 655-685. https://doi.org/10.1177/ 0170840615622066

Steinmann, Z. J. N., Huijbregts, M. A. J., \& Reijnders, L. (2019). How to define the quality of materials in a circular economy? Resources, Conservation and Recycling, 141, 362-363. https://doi.org/10.1016/j. resconrec.2018.10.040

Testa, F., Nucci, B., Iraldo, F., Appolloni, A., \& Daddi, T. (2017). Removing obstacles to the implementation of LCA among SMEs: A collective strategy for exploiting recycled wool. Journal of Cleaner Production, 156, 923-931. https://doi.org/10.1016/j.jclepro.2017.04.101

Tukker, A. (2015). Product services for a resource-efficient and circular economy-A review. Journal of Cleaner Production, 97, 76-91. https:// doi.org/10.1016/j.jclepro.2013.11.049 
UNIC (Unione Nazionale Industria Conciaria), 2015. Rapporto di Sostenibilità 2015. Milano available from: www.unic.it.

Van der Byl, C. A., \& Slawinski, N. (2015). Embracing tensions in corporate sustainability: A review of research from win-wins and trade-offs to paradoxes and beyond. Organization \& Environment, 28(1), 54-79.

Vilanova, M., Lozano, J. M., \& Arenas, D. (2009). Exploring the nature of the relationship between CSR and competitiveness. Journal of Business Ethics, 87, 57-69. https://doi.org/10.1007/s10551-008-9812-2

Yin, R. K. (1981). The case study as a serious research strategy. Knowledge, 3(1), 97-114. https://doi.org/10.1177/107554708100300106
Yin, R. K. (2009). Case study research, Design \& Methods 4th ed. London and Singapore: SAGE

How to cite this article: Daddi T, Ceglia D, Bianchi G, de Barcellos MD. Paradoxical tensions and corporate sustainability: A focus on circular economy business cases. Corp Soc Resp Env Ma. 2019;1-11. https://doi.org/10.1002/csr.1719 